J. Appl. Glycosci., 51, 327-333 (2004)

(C) 2004 The Japanese Society of Applied Glycoscience

\title{
Further Structural Study of the Barley and Bamboo Shoot Xyloglucans by Xyloglucanase
}

\author{
(Received July 5, 2004 ; Accepted August 12, 2004)
}

Yoji Kato, ${ }^{1, *}$ Seiko Ito ${ }^{1}$ and Yasushi Mitsuishi ${ }^{2}$

\begin{abstract}
${ }^{1}$ Laboratory of Food Science, Faculty of Education, Hirosaki University (1, Bunkyo-cho, Hirosaki 036-8560, Japan) ${ }^{2}$ The Institute for Biological Resources and Functions, National Institute of Advanced Industrial Science and Technology, Tsukuba Central 6 (1-1-1, Higashi, Tsukuba 305-8566, Japan)
\end{abstract}

\begin{abstract}
To investigate the arrangement of the glucose residues which are not xylosylated at $O-6$ in the $\beta$ 1,4-D-glucan backbone of xyloglucan from Gramineae, a xyloglucan from immature barley plants was hydrolyzed by a purified Geotrichum sp. M128 xyloglucan specific endo-1,4- $\beta$-D-glucanase (xyloglucanase). The fragment oligosaccharides were then analyzed by matrix-assisted laser-desorption ionization time of the flight mass spectrometry before and after treatment with an oligoxyloglucan-specific glycosidase, oligoxyloglucan reducing end-specific cellobiohydrolase from Geotrichum sp. M128, with a mixture of isoprimeverose-producing oligoxyloglucan hydrolase from Eupenicillium sp. M9 and $\beta$-D-glucosidase from Trichoderma viride, or with $\beta$-D-galactosidase from Bacillus circulans. Tetra-, penta-, hexa-, hepta-, octa- and nona-saccharide fractions were obtained as major oligosaccharide fractions, which might be composed of XX, of XXG, of XXGG, of XXGGG and LXGG, of XLGgG, LXGGg, XXGGGG and GXXGGG, and of XLGGGG, LXGGGG, GXLGGG, GLXGGG and XXGGGGG, respectively. In addition, the oligosaccharide units of bamboo shoot xyloglucan were analyzed. The structure of bamboo shoot xyloglucan was shown to be very similar to that of barley xyloglucan. These results suggest that the Gramineae xyloglucan has regions consisting of two, three, four and five contiguous glucose residues which are not xylosylated at $O-6$ in the $\beta$-1,4-D-glucan backbone.
\end{abstract}

Key words: barley, bamboo shoot, xyloglucan oligosaccharides, Gramineae, xyloglucanase

Xyloglucan is a major structural polysaccharide of the primary cell-walls of all higher plants. ${ }^{2)} \mathrm{A}$ marked characteristic of the xyloglucan is that the polysaccharide consists of a linear backbone chain of 1,4-linked $\beta$-Dglucosyl residues and side chains of single $\alpha$-D-xylosyl residues, $\alpha$-L-fucosyl- $(1 \rightarrow 2)$ - $\beta$-D-galactosyl- $(1 \rightarrow 2)-\alpha$-Dxylosyl residues, $\beta$-D-galactosyl-( $1 \rightarrow 2)-\alpha$-D-xylosyl residues, and others that are attached to the $O$-6-positions of the backbone chain. Treatment of most xyloglucans from

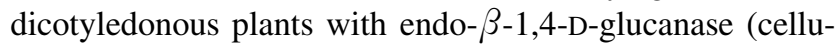
lase) generates mainly oligosaccharide subunits, XXXG, XLXG, XXLG, XLLG, XXFG and XLFG. ${ }^{3)}$ Specifically, the xyloglucan of most dicotyledonous plants is built from

\footnotetext{
${ }^{*}$ Corresponding author (Tel. \& Fax. +81-172-39-3436, E-mail: ykato@cc.hirosaki-u.ac.jp).

Abbreviations: Xyl, D-xylose; Glc, D-glucose; Gal, D-galactose; Ara, L-arabinose; IP $[\alpha-\mathrm{Xyl}-(1 \rightarrow 6)-\mathrm{Glc}]$, isoprimeverose; GG, XX, XXG，XXXG，XLXG，XXLG，XLLG，XXFG，XLFG, XXGG, XLGG, LXGG, XSGG, LSGG, XXGGG, XLGGG, LXGGG, XXGGGG, GXXGGG, XLGGGG, LXGGGG, GXLGGG, GLXGGG and XXGGGGG are the abbreviated names for xyloglucan oligosaccharides according to the nomenclature of Fry et al. [Ref. 1) Each $(1 \rightarrow 4)-\beta$-linked D-glucosyl residue in the backbone is given a one-letter code according to its substituents: $\mathrm{G}=\beta$-Glc; $\mathrm{X}=\alpha$-Xyl- $(1 \rightarrow 6)-\beta$-Glc; $\mathrm{L}=\beta$-Gal- $(1 \rightarrow 2)-\alpha-\mathrm{Xyl}-(1$ $\rightarrow 6)-\beta$-Glc; $\mathrm{S}=\alpha$-Ara- $(1 \rightarrow 2)-\alpha$-Xyl- $(1 \rightarrow 6)-\beta$-Glc; $\mathrm{F}=\alpha$-Fuc- $(1$ $\rightarrow 2)-\beta$-Gal- $(1 \rightarrow 2)-\alpha$-Xyl- $(1 \rightarrow 6)-\beta$-Glc]. IPase, isoprimeveroseproducing oligoxyloglucan hydrolase; $\mathrm{Xg}$-ase, xyloglucanase; Oxg-RCBH, oligoxyloglucan reducing end-specific cellobiohydrolase; $\beta$-D-galase, $\beta$-D-galactosidase; $\beta$-D-glcase, $\beta$-D-glucosidase; CMCase, carboxymethylcellulase; HPLC, high-performance liquid chromatography ; MALDI-TOF-MS , matrix-assisted laserdesorption ionization time of the flight mass.
}

XXXG-type subunits.

The xyloglucans from Gramineae G) $^{4-6}$ and Solanaceae $^{7-12)}$ have more unsubstituted Glc residues compared to those from most dicotyledonous plants. We previously investigated the branching pattern and the arrangement of the glucosyl residues which are not xylosylated at $O-6$ in the $\beta$-1,4-D-glucan backbone of Solanaceae xyloglucans, using a purified Penicillium sp. M451 xyloglucan specific endo-1,4- $\beta$-D-glucanase (xyloglucanase, $\mathrm{Xg}$-ase), and confirmed that the xyloglucan from most solanaceous vegetables (eggplant, sweet pepper, red pepper and tomato) is built from XXGG-type subunits (XXGG, XLGG, LXGG, XSGG and LSGG). ${ }^{13)}$

On the other hand, we previously characterized the structures of xyloglucans obtained from the cell-walls of immature barley and rice plants, and bamboo shoot. ${ }^{4-6)}$ Treatment of Gramineae xyloglucans with endo- $\beta-1,4-\mathrm{D}-$ glucanase (cellulase) generated glucose $(\mathrm{G})$ and cellobiose (GG) in addition to oligosaccharides, XXGG, XXG, XX, $\mathrm{XG}$, etc. However, it has not been certain whether or not Gramineae xyloglucans are built from oligosaccharide subunits. To clarify this question, we hydrolyzed barley xyloglucan with Geotrichum sp. M128 xyloglucan specific endo-1,4- $\beta$-D-glucanase (xyloglucanase, $\mathrm{Xg}$-ase) and carried out analysis of the fragment oligosaccharides of barley xyloglucan by digestion with various kinds of enzymes followed by matrix-assisted laser-desorption ionization time of the flight mass (MALDI-TOF-MS). In addition we characterized the structure of fragment oligosaccharides from bamboo shoot xyloglucan. This report deals with the results. 


\section{MATERIALS AND METHODS}

Barley and bamboo shoot xyloglucans. The hemicellulose IIA fraction obtained from cell walls of immature barley plant, ${ }^{4)}$ which consists of Glc, Xyl, Gal and Ara in a molar ratio of $57.4: 30.0: 9.3: 3.3$, was used as a barley xyloglucan for this study.

Bamboo shoot xyloglucan was prepared as described previously. ${ }^{6}$

Enzymes. A xyloglucan specific endo-1,4- $\beta$-Dglucanase (Xg-ase) and an oligoxyloglucan-specific glycosidase, oligoxyloglucan reducing endo-specific cellobiohydrolase (Oxg-RCBH) from Geotrichum sp. M128, an isoprimeverose-producing oligoxyloglucan hydrolase (IPase) from Eupenicillium sp. M9 and an endo-1,4- $\beta$-Dglucanase (carboxymethylcellulase, CMCase) and $\beta$-Dglucosidase ( $\beta$-D-glcase) from $T$. viride which were purified to their respective electrophoretically pure states, were used. M128 Xg-ase can hydrolyze the glucosidic bonds between unbranched Glc residues and $O-4$ of 4,6disubstituted Glc residues, but can not hydrolyze Avicel SF, phosphoric acid swollen cellulose, carboxymethyl cellulose, hydroxyethyl cellulose or cellooligosaccharides. ${ }^{14)}$ M128 Oxg-RCBH has exoglucanase activity, and it recognizes the reducing end of oligoxyloglucan and releases two glucosyl residue segments from the main chain. ${ }^{15)}$ M9 IPase is highly specific for xyloglucan oligosaccharides and splits off isoprimeverose units from the non-reducing end of the backbone of the substrate; it can not by-pass the glucosyl residues substituted with $\beta$-Gal- $(1 \rightarrow 2)-\alpha$ $\mathrm{Xyl}$, or $\alpha$-Fuc- $(1 \rightarrow 2)-\beta$-Gal- $(1 \rightarrow 2)-\alpha$-Xyl side chains. ${ }^{16)}$ $\beta$-D-Galactosidase (Biolacta-N5, $\beta$-D-galase) from Bacillus circulans purchased from Daiwa Kasei K.K., was entirely free from IPase.

General methods. Total carbohydrate was determined by the phenol-sulfuric acid method. ${ }^{17}$

Hydrolysis of barley xyloglucan with Geotrichum M 128 xyloglucanase (Xg-ase). Barley xyloglucan $(8.1 \mathrm{mg}$ as Glc equiv. in $180 \mu \mathrm{L}$ of $20 \mathrm{mM} \mathrm{Na}$-acetate buffer, $\mathrm{pH}$ 5.5) was incubated with Geotrichum M128 Xg-ase (0.01 $\mathrm{U} / 20 \mu \mathrm{L})$ at $40^{\circ} \mathrm{C}$. After $24 \mathrm{~h}$, the incubation mixture was heated for $10 \mathrm{~min}$ in a boiling water-bath, and treated with Amberlite IR-120 $\left(\mathrm{H}^{+}\right)$.

Hydrolysis of barley xyloglucan with T. viride CMCase. Barley xyloglucan $(8.1 \mathrm{mg}$ as Glc equiv. in $180 \mu \mathrm{L}$ of $20 \mathrm{mM}$ Na-acetate buffer, $\mathrm{pH} 5.5)$ was incubated with $T$. viride CMCase $(0.01 \mathrm{U} / 20 \mu \mathrm{L})$ at $40^{\circ} \mathrm{C}$. After $24 \mathrm{~h}$, the incubation mixture was heated for $10 \mathrm{~min}$ in a boiling water-bath, and treated with Amberlite IR-120 $\left(\mathrm{H}^{+}\right)$.

High-performance liquid chromatography (HPLC) of the Xg-ase-hydrolyzate and the CMCase-hydrolyzate.

HPLC was performed on a column $(4.6 \times 250 \mathrm{~mm})$ of $\mathrm{Li}-$ chrosorb $\mathrm{NH}_{2}$. The hydrolyzates were eluted with $\mathrm{CH}_{3} \mathrm{CN}$ : $\mathrm{H}_{2} \mathrm{O}=70: 30$ at a flow rate of $0.8 \mathrm{~mL} / \mathrm{min}$. In the case of the $\mathrm{Xg}$-ase-hydrolyzate, fractions 1 to 18 as shown in Fig. 2 were obtained respectively. Fractions 3, 5, 8, 10, 13 and 17 were rechromatographed on the same column, respectively.

Hydrolysis of xyloglucan oligosaccharide fractions with a mixture of $\beta$-D-glcase and IPase. Fractions of xyloglucan oligosaccharides $(50 \mu \mathrm{g}$ as Glc equiv. in 50 $\mu \mathrm{L}$ of $20 \mathrm{~mm} \mathrm{Na-acetate}$ buffer, $\mathrm{pH} 5.5$ ) were incubated individually at $40^{\circ} \mathrm{C}$ with a mixture of $\beta$-D-glcase and IPase $(0.01 \mathrm{U}$ each/10 $\mu \mathrm{L})$. After $48 \mathrm{~h}$, the fractions were heated in a boiling water-bath for $10 \mathrm{~min}$, and deionized with Amberlite IR-120 $\left(\mathrm{H}^{+}\right)$.

Hydrolysis of xyloglucan oligosaccharide fractions with $\mathrm{O} \boldsymbol{x} \boldsymbol{g}-\mathrm{RCBH}$. Fractions of xyloglucan oligosaccharides $(50 \mu \mathrm{g}$ as Glc equiv. in $50 \mu \mathrm{L}$ of $20 \mathrm{~mm} \mathrm{Na-acetate}$ buffer, pH 5.5) were incubated individually at $40^{\circ} \mathrm{C}$ with Oxg-RCBH $(0.01 \mathrm{U} / 20 \mu \mathrm{L})$. After $48 \mathrm{~h}$, the fractions were heated in a boiling water-bath for $10 \mathrm{~min}$, and deionized with Amberlite IR-120 $\left(\mathrm{H}^{+}\right)$.

Hydrolysis of xyloglucan oligosaccharide fractions with $\beta$-D-galase. Fractions of xyloglucan oligosaccharides $(50 \mu \mathrm{g}$ as Glc equiv. in $50 \mu \mathrm{L}$ of $50 \mathrm{~mm} \mathrm{Na}$-acetate buffer, pH 6.0) were incubated individually at $40^{\circ} \mathrm{C}$ with $\beta$-D-galase $(0.01 \mathrm{U} / 10 \mu \mathrm{L})$. After $24 \mathrm{~h}$, the fractions were heated in a boiling water-bath for $10 \mathrm{~min}$, and deionized with Amberlite IR-120 $\left(\mathrm{H}^{+}\right)$.

Matrix-assisted laser-desorption ionization time of the flight mass (MALDI-TOF-MS). An aqueous solution $(0.5 \mu \mathrm{L}$, about $50 \mu \mathrm{g} / \mathrm{mL})$ of each sample was mixed with an equal volume of $1 \%$ 2,5-dihydroxybenzoic acid in $40 \%$ acetonitrile aqueous solution. This mixture was applied to the MALDI probe and dried. MALDI-TOF-MS was recorded with a Voyager RP (PerSeptive Biosystems, USA) operating at a $20 \mathrm{kV}$ accelerating voltage. ${ }^{18)}$

\section{RESULTS AND DISCUSSION}

\section{Barley xyloglucan.}

1. Hydrolysis of barley xyloglucan with Geotrichum $X g$-ase and fractionation of the Xg-ase hydrolyzate.

We previously characterized a xyloglucan occurring in the hemicellulose II fraction (HC-IIA, Glc : Xyl : Gal : Ara $=57.4: 30.0: 9.3: 3.3$ ) of cell walls of immature barley plants by methylation and fragmentation analyses. The fragmentation of HC-IIA (xyloglucan) was done by hydrolysis with $T$. viride CMCase. The structures of the obtained oligosaccharides were proposed to be XXGG (hexasaccharide), XXG (pentasaccharide), XG (trisaccharide), GG (cellobiose) and G (glucose). In the present study, barley xyloglucan was hydrolyzed with Geotrichum sp. M 128 xyloglucan specific endo-1,4- $\beta$-D-glucanase (xyloglucanase, Xg-ase). HPLC analysis showed that the M128 $\mathrm{Xg}$-ase-hydrolysis products of barley xyloglucan were clearly different from the CMCase-hydrolysis products of barley xyloglucan (Fig. 1). Namely, an unnegligible amount of higher molecular weight oligosaccharides are found in the M128 Xg-ase-hydrolysis products.

The M128 Xg-ase-hydrolysis products were subjected to a preparative HPLC on a column of Lichrosorb $\mathrm{NH}_{2}$. Fractions 1 to 18 were obtained in a ratio of $5.5: 0.8$ : $4.0: 2.7: 11.3: 2.6: 2.6: 17.2: 4.2: 25.7: 2.1: 1.9: 9.4$ : $3.5: 1.0: 0.5: 4.3: 0.8$ (Fig. 2). Fractions 3, 5, 8, 10, 13 and 17 were purified by the chromatography on the same column. Then, the predominant oligosaccharide fractions were subjected to the respective MALDI-TOF-MS analysis before and after treatment with enzymes. 


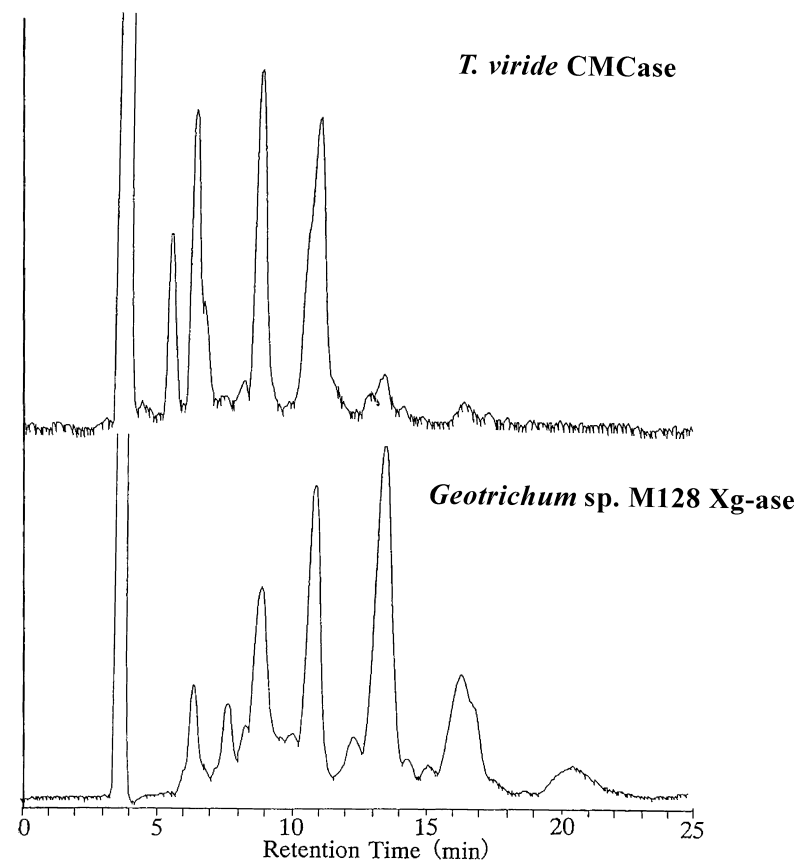

Fig. 1. HPLC of M128 Xg-ase-hydrolyzate and CMCasehydrolyzate of barley xyloglucan.



Fig. 2. Separation of the $\mathrm{Xg}$-ase hydrolysis products of barley $\mathrm{xy}-$ loglucan by HPLC.

Barley xyloglucan $(8.1 \mathrm{mg}$ as Glc equiv. in $180 \mu \mathrm{L}$ of $20 \mathrm{~mm}$ Na-acetate buffer, pH 5.5) was incubated with Geotrichum M128 $\mathrm{Xg}$-ase at $40^{\circ} \mathrm{C}$. After $24 \mathrm{~h}$, the incubation mixture was heated for 10 min in a boiling water-bath and treated with Amberlite IR-120 $\left(\mathrm{H}^{+}\right)$. HPLC was performed on a column $(4.6 \times 250 \mathrm{~mm})$ of Lichrosorb $\mathrm{NH}_{2}$. The hydrolyzates were eluted with $\mathrm{CH}_{3} \mathrm{CN}: \mathrm{H}_{2} \mathrm{O}=70$ : 30 at a flow rate of $0.8 \mathrm{~mL} / \mathrm{min}$. Fractions 3, 5, 8, 10, 13 and 17 were rechromatographed on the same column.

\section{Analysis of oligosaccharides in fractions 3, 5 and 8.}

Fractions 3, 5 and 8 were subjected to MALDI-TOFMS analysis, respectively. In the mass spectra, the ion peaks at $\mathrm{m} / \mathrm{z} 627.637,789.016$ and 951.162 correspond to the molecular ions as sodium adduct $[\mathrm{M}+\mathrm{Na}]^{+}$of the tetrasaccharide, (hexose $)_{2}(\text { pentose })_{2}$, the pentasaccharide, (hexose $)_{3}(\text { pentose })_{2}$, and the hexasaccharide, (hexose) $)_{4}$ (pentose) $)_{2}$, were observed (data not shown). In our previous study, tetrasaccharide (Glc: $\mathrm{Xyl}=2: 2$ ), pentasaccharide (Glc: $\mathrm{Xyl}=3: 2)$ and hexasaccharide (Glc: Xyl=4:2) were isolated from the $T$. viride cellulase hydrolyzate of barley xyloglucan and were characterized to be XX, XXG and XXGG, respectively (Fig. 3). The tetra-, penta- and hexa-saccharides obtained in the present study are considered to be the same oligosaccharides obtained previously. Therefore, further study of these oligosaccharide fractions was not carried out.


Fig. 3. Proposed structures of oligosaccharides in fractions 3,5 and 8 obtained from barley xyloglucan by Geotrichum M128 Xg-ase.

Symbols in figures: Glc, $\beta$-Glc- $(1 \rightarrow 4)-$; $X y l, \alpha-X y l-(1 \rightarrow 6)-$. Symbols in $\square$, see abbreviations.

\section{Analysis of oligosaccharides in fraction 10.}

Fraction 10 was subjected to MALDI-TOF-MS analysis. In the mass spectra, the ion peaks at $\mathrm{m} / \mathrm{z} 1114.18$ and 1130.15 , which correspond to the molecular ions as sodium adduct $[\mathrm{M}+\mathrm{Na}]^{+}$and potassium adduct $[\mathrm{M}+\mathrm{K}]^{+}$ of the heptasaccharide, (hexose $)_{5}(\text { pentose })_{2}$, were observed (Fig. 4A). Our previous study indicated that barley xyloglucan contained Gal residues as constituent monosaccharide. The (hexose $)_{5}$ (pentose $)_{2}$ may correspond to $(\mathrm{Glc})_{5}$ $(\mathrm{Xyl})_{2}$ and/or $(\mathrm{Glc})_{4}(\mathrm{Xyl})_{2}(\mathrm{Gal})_{1}$. The branching pattern and the arrangement of the Glc residues in the oligosaccharides, $(\mathrm{Glc})_{5}(\mathrm{Xyl})_{2}$ and/or $(\mathrm{Glc})_{4}(\mathrm{Xyl})_{2}(\mathrm{Gal})_{1}$ were investigated as follows.

First the heptasaccharide fraction was treated with $\beta$-Dgalase and the hydrolyzate was subjected to MALDITOF-MS analysis. In the mass spectrum (Fig. 4B), peaks at $\mathrm{m} / \mathrm{z} 953.34$ and 969.313 corresponding to [(hexose $)_{4}$ $\left.(\text { pentose })_{2}+\mathrm{Na}\right]^{+}$and $\left[(\text {hexose })_{4}(\text { pentose })_{2}+\mathrm{K}\right]^{+}$, and the peaks at $\mathrm{m} / \mathrm{z} 1115.46$ and 1131.43 corresponding to $\left[(\text { hexose })_{5}(\text { pentose })_{2}+\mathrm{Na}\right]^{+}$and $\left[(\text {hexose })_{5}(\text { pentose })_{2}\right.$ $+\mathrm{K}]^{+}$were observed (Fig. 4B). The (hexose $)_{4}(\text { pentose })_{2}$ may correspond to a $(\mathrm{Glc})_{4}(\mathrm{Xyl})_{2}$. The (hexose $)_{5}(\text { pentose })_{2}$ is considered to be $(\mathrm{Glc})_{5}(\mathrm{Xyl})_{2}$.

Secondly the heptasaccharide fraction was partially hydrolyzed with M9 IPase and the partial hydrolyzate was subjected to MALDI-TOF-MS analysis. In the MALDITOF-MS spectrum of the IPase-partially hydrolyzed heptasaccharide fraction (Fig. 4C), peaks at $\mathrm{m} / \mathrm{z} 528.4$ and 544.077 corresponding to $\left[(\text { hexose })_{3}+\mathrm{Na}\right]^{+}$and $\left[(\text { hexose })_{3}+\mathrm{K}\right]^{+}$, peaks at $\mathrm{m} / \mathrm{z} 822.615$ and 838.343 corresponding to $\left[(\text { hexose })_{4}(\text { pentose })_{1}+\mathrm{Na}\right]^{+}$and $\left[(\text {hexose })_{4}\right.$ (pentose $\left.)_{1}+\mathrm{K}\right]^{+}$in addition to the original peaks at $\mathrm{m} / \mathrm{z}$ 1116.78 and 1132.77 corresponding to $\left[(\text { hexose })_{5}\right.$ (pentose $\left.)_{2}+\mathrm{Na}\right]^{+}$and $\left[(\text {hexose })_{5}(\text { pentose })_{2}+\mathrm{K}\right]^{+}$, were observed. The (hexose $)_{4}(\text { pentose })_{1}$ and (hexose) $)_{3}$ are considered to be XGGG $\left[(\mathrm{Glc})_{4}(\mathrm{Xyl})_{1}\right]$ and GGG $\left[(\mathrm{Glc})_{3}\right]$, respectively. The former and the latter are considered to be produced by splitting off one isoprimeverose (X) unit and two isoprimeverose units from the non-reducing end of the backbone of XXGGG by M9 IPase, respectively. The (hexose $)_{5}$ (pentose $)_{2}$ is considered to be LXGG, because LXGG is not hydrolyzed by IPase.

On the basis of the modes of action of M128 Xg-ase, M9 IPase and $\beta$-D-galase, it is reasonable to conclude that heptasaccharide contains XXGGG and LXGG (Fig. 5).

\section{Analysis of oligosaccharides in fraction 13.}

Fraction 13 was subjected to MALDI-TOF-MS analysis. In the mass spectrum, an ion peak at $\mathrm{m} / \mathrm{z} 1278.1$, which corresponds to the molecular ions as sodium adduct 

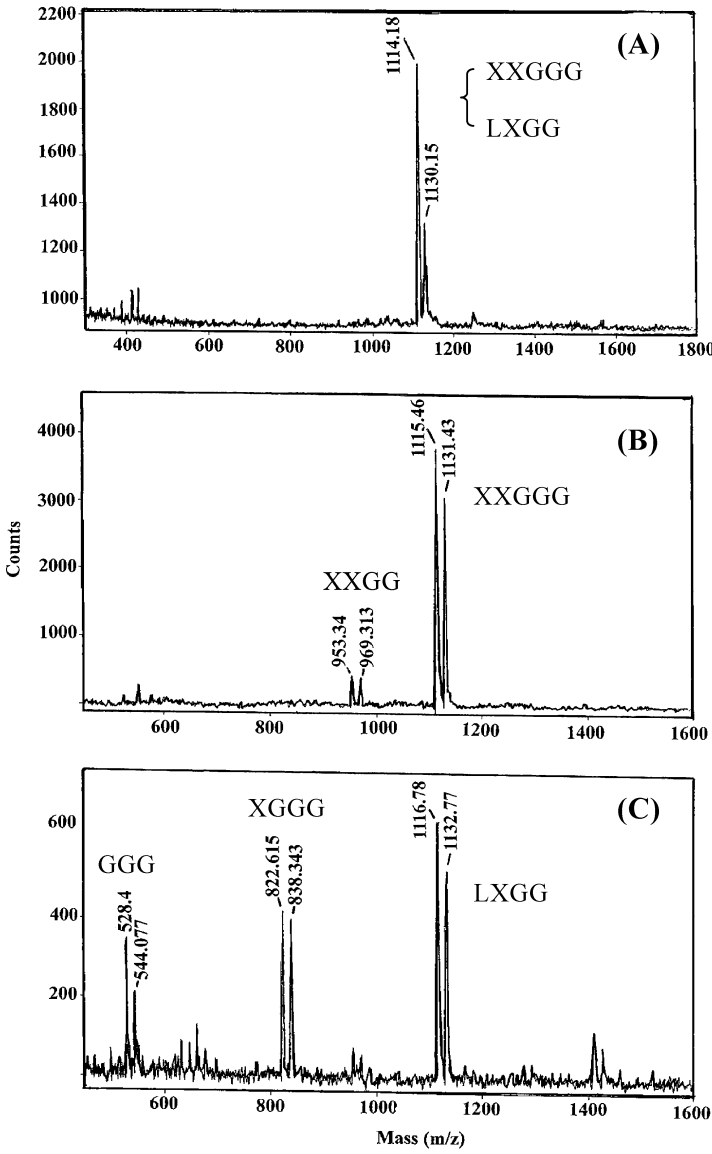

Fig. 4. MALDI-TOF-MS of fraction 10 (A), of $\beta$-D-galase treated fraction $10(\mathrm{~B})$, and of M9 IPase-partially treated fraction $10(\mathrm{C})$.

\begin{tabular}{|c|c|c|}
\hline \multirow{2}{*}{$\begin{array}{l}\text { oligosaccharide in } \\
\text { fr.10 }\end{array}$} & \multicolumn{2}{|c|}{ oligosaccharides obtained by } \\
\hline & $\beta$-D-galase & M9 IPase \\
\hline Xyl Xyl & Xyl Xyl & Xyl Xyl \\
\hline $\begin{array}{c}\text { Gle-Glc-Glc-Glc-Glc } \\
\text { XXGGG } \\
\end{array}$ & $\begin{array}{c}\text { Gle }- \text { Glc }- \text { Glc-Gle-Gle } \\
\text { XXGGG } \\
\end{array}$ & $\begin{array}{lll}\text { Gle } & \text { Glc } & \text { Gle-Gle-Gl } \\
\mathbf{X} & \mathbf{X} & \mathbf{G G G} \\
\end{array}$ \\
\hline Gal & Gal & Gal \\
\hline Xyl Xyl & Xyl Xyl & Xyl Xyl \\
\hline Gle-Gle-Gle-Gle & Gle-Gle-Gle-Gle & Gle - Gle - Gle$-G l e$ \\
\hline \begin{tabular}{|l|l|} 
LXGG \\
\end{tabular} & \begin{tabular}{|l|} 
XXGG \\
\end{tabular} & \begin{tabular}{|l|l|} 
LXGG \\
\end{tabular} \\
\hline
\end{tabular}

Fig. 5. Proposed structures of oligosaccharides in fraction 10, and those of oligosaccharides obtained by hydrolysis of fraction 10 with $\beta$-D-galase or M9 IPase.

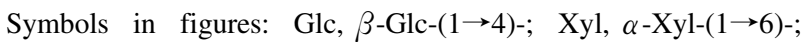
Gal, $\beta$-Gal-( $(1 \rightarrow 2)-$. Symbols in $\square$, see abbreviations.

$\left[(\text { hexose })_{6}(\text { pentose })_{2}+\mathrm{Na}\right]^{+}$of the octasaccharide, was observed (data not shown). Fraction 13 was treated with $\beta$ D-galase and the hydrolyzate was subjected to MALDITOF-MS analysis. In the mass spectrum (Fig. 6A), a peak at $\mathrm{m} / \mathrm{z} 1116.64$ corresponding to $\left[(\text { hexose })_{5}\left(\right.\right.$ pentose $_{2}$ $+\mathrm{Na}]^{+}$in addition to the peak at $\mathrm{m} / \mathrm{z} 1278.71$ corresponding to $\left.[\text { (hexose })_{6}(\text { pentose })_{2}+\mathrm{Na}\right]^{+}$was observed (Fig. 6A). This means fraction 13, (hexose) $)_{6}(\text { pentose })_{2}$, may correspond to $(\mathrm{Glc})_{6}(\mathrm{Xyl})_{2}$ and $(\mathrm{Glc})_{5}(\mathrm{Xyl})_{2}(\mathrm{Gal})_{1}$. On the basis of the modes of action of M128 Xg-ase, the octasaccharides in fraction 13 are supposed to be XLGGG, LXGGG, XXGGGG and/or GXXGGG.

To make clear this supposition, first fraction 13 was

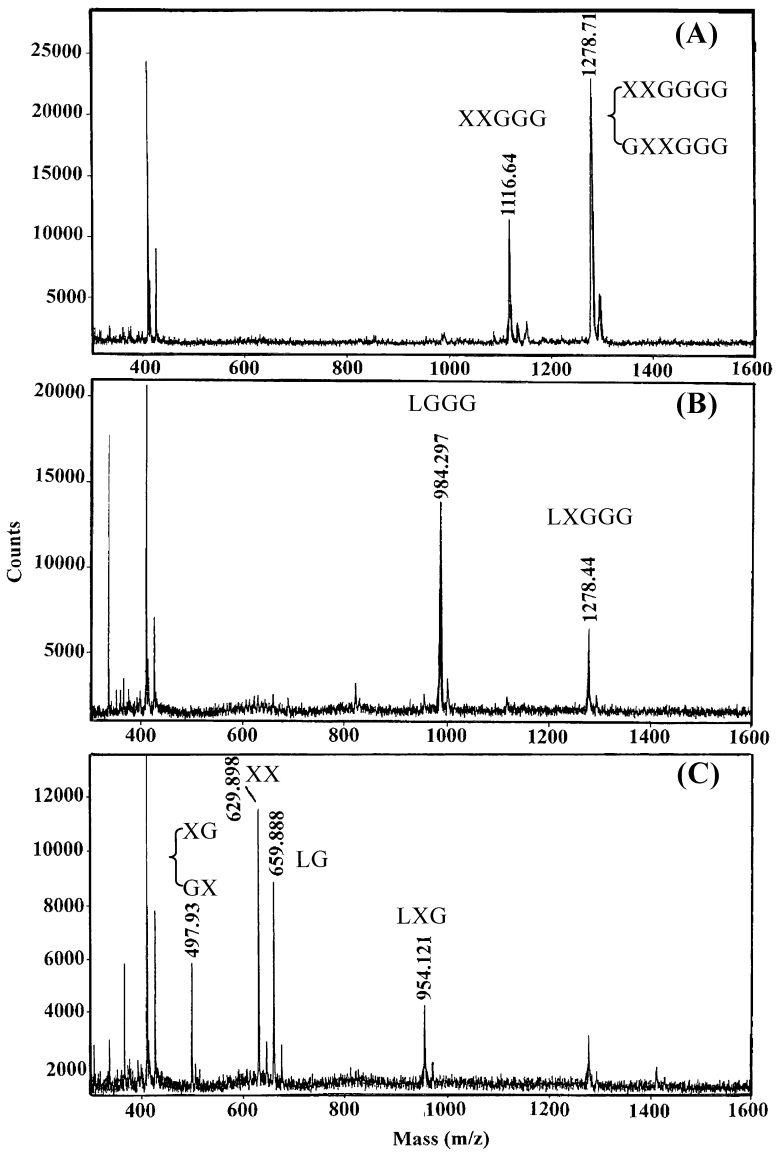

Fig. 6. MALDI-TOF-MS of $\beta$-D-galase treated fraction 13 (A), of $\beta$-D-glcase and M9 IPase treated fraction 13 (B), and of Oxg-RCBH treated fraction 13 (C).

treated with a mixture of $\beta$-D-glcase and IPase and the product was subjected to MALDI-TOF-MS analysis (Fig. 6B). Peaks at $\mathrm{m} / \mathrm{z} 984.297$ corresponding to (hexose $)_{5}(\text { pentose })_{1}$ and 1278.44 corresponding to (hexose $)_{6}(\text { pentose })_{2}$ were observed. The former is considered to correspond to the oligosaccharide LGGG which was produced from XLGGG by IPase, and the latter is considered to correspond to the oligosaccharide LXGGG which was not hydrolyzed by both $\beta$-D-glcase and IPase. The oligosaccharides XXGGGG and GXXGGG were hydrolyzed into $X$ (isoprimeverose) and $G$ (glucose) by the $\beta$-D-glcase and IPase.

Secondly fraction 13 was treated with Oxg-RCBH and the product was subjected to MALDI-TOF-MS analysis (Fig. 6C). The peaks at m/z 954.121 and 659.888 in the mass spectrum correspond to (hexose) $)_{4}(\text { pentose) })_{2}$ and (hexose) $)_{3}(\text { pentose })_{1}$, respectively. The hexasaccharide, (hexose) $)_{4}(\text { pentose })_{2}$, and the tetrasaccharide, (hexose) $)_{3}$ (pentose), are considered to be LXG and LG, respectively, which were produced from LXGGG and XLGGG. In the mass spectrum the peak at $\mathrm{m} / \mathrm{z} 629.898$ corresponding to (hexose $)_{2}$ (pentose) $)_{2}$ is considered to be XX, which is produced from only XXGGGG by Oxg-RCBH. In addition the peak at $\mathrm{m} / \mathrm{z} 497.93$ corresponding to (hexose) 2 (pentose) $)_{1}$ is considered to be GX and XG, both of which are produced from only GXXGGG by Oxg-RCBH.

On the basis of the modes of action of M128 Xg-ase, M9 IPase, $\beta$-D-glcase, $\beta$-D-galase and Oxg-RCBH it is reasonable to conclude that octasaccharide contains XLGGG, LXGGG, XXGGGG and GXXGGG (Fig. 7). 


\begin{tabular}{|c|c|c|c|}
\hline \multirow{2}{*}{$\begin{array}{l}\text { oligosaccharide in } \\
\text { fr. } 13\end{array}$} & \multicolumn{3}{|c|}{ oligosaccharides obtained by } \\
\hline & $\beta-\mathrm{I}$ & $\beta$-D-glcase & Oxg-RCBH \\
\hline 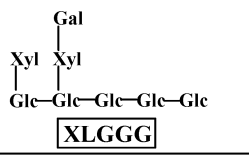 & $\begin{array}{c}\text { Gal } \\
\text { Xyl } \\
\int_{\text {Gyl }} \\
\text { Gle-Glc-Gle-Gle-Glc } \\
\text { XXGGG } \\
\end{array}$ & 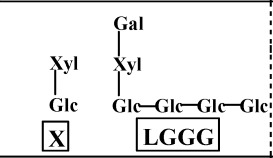 & \begin{tabular}{|lll} 
& Gal \\
Xyl & $\int_{\text {Xyl }}$ \\
$\int_{\text {Glc }}$ & $\left.\right|_{\text {Glc-Glc }}$ Gle-Glc \\
X & LG & GG \\
\end{tabular} \\
\hline $\begin{array}{l}\text { Gal } \\
\text { Xyl Xyl } \\
\text { Gle-Gle-Glc-Gle-Glc } \\
\text { LXGGG }\end{array}$ & $\begin{array}{l}\text { Gal } \\
\text { Yyl Xyl } \\
\int_{\text {Gle-Gle-Glc-Glc-Glc }} \\
\text { XXGGG }\end{array}$ & $\begin{array}{l}\text { Gal } \\
\int_{\text {Xyl }}^{\text {Xyl }} \\
\int_{\text {Gle-Glc-Gle-Glc-Glc }} \\
\text { LXGGG }\end{array}$ & 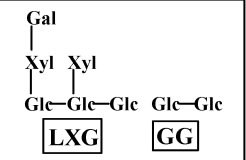 \\
\hline $\begin{array}{c}\text { Xyl } \int_{\text {Gle-Gle-Gle-Gle-Gle-Gle }}^{\text {Gle }} \\
\quad \text { XXGGGG }\end{array}$ & $\begin{array}{l}\text { Xyl } \\
\text { Gle-Gle-Gle-Gle-Gle-Gle } \\
\text { XXGGGG }\end{array}$ & 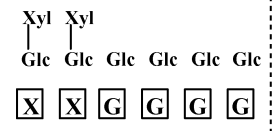 & 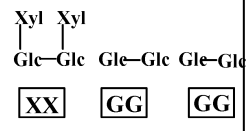 \\
\hline $\begin{array}{c}\int_{\text {Gle-Gle-Gle-Gle-Gle-Gle }}^{\mathrm{Xyl}} \int^{\mathrm{yyl}} \\
\text { GXXGGG }\end{array}$ & $\begin{array}{c}\int_{\text {Gle-Gle-Gle-Gle-Gle-Gice }}^{\mathrm{Xyl}} \text { Xyl } \\
\text { GXXGGG }\end{array}$ & 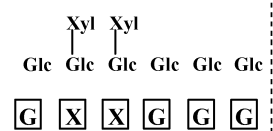 & 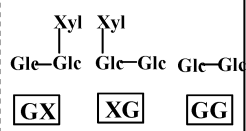 \\
\hline
\end{tabular}

Fig. 7. Proposed structures of oligosaccharides in fraction 13, and those of oligosaccharides obtained by hydrolysis of fraction 13 with $\beta$-D-galase, with $\beta$-D-glcase and M9 IPase, or with Oxg-RCBH.

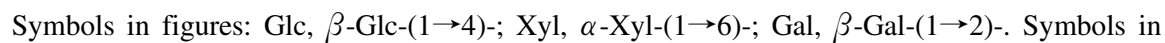
$\square$, see abbreviations.

\section{Analysis of oligosaccharides in fraction 17.}

Fraction 17 was subjected to MALDI-TOF-MS analysis. In the mass spectrum, an ion peak at $\mathrm{m} / \mathrm{z} 1441.08$ which corresponds to the molecular ions as sodium adduct $\left[(\text { hexose })_{7}(\text { pentose })_{2}+\mathrm{Na}\right]^{+}$of the nonasaccharide was observed (data not shown). Fraction 17 was treated with $\beta$-D-galase and the hydrolyzate was subjected to MALDITOF-MS analysis. In the mass spectrum, a peak at $\mathrm{m} / \mathrm{z}$ 1278.95 corresponding to $\left[(\text { hexose })_{6}(\text { pentose })_{2}+\mathrm{Na}\right]^{+}$in addition to the peak at $\mathrm{m} / \mathrm{z} 1441.08$ corresponding to $\left[(\text { hexose })_{7}(\text { pentose })_{2}+\mathrm{Na}\right]^{+}$was observed (Fig. 8A). This means fraction 17 , (hexose $)_{7}(\text { pentose })_{2}$ may correspond to $(\mathrm{Glc})_{7}(\mathrm{Xyl})_{2}$ and $(\mathrm{Glc})_{6}(\mathrm{Xyl})_{2}(\mathrm{Gal})_{1}$. On the basis of the modes of action of M128 Xg-ase, the nonasaccharides in fraction 17 are supposed to be XLGGGG, GXLGGG, GLXGGG and/or XXGGGGG.

To make clear this supposition, first fraction 17 was treated with a mixture of $\beta$-D-glcase and IPase and the product was subjected to MALDI-TOF-MS analysis (Fig. 8B). The peak at $\mathrm{m} / \mathrm{z} 1440.74$ corresponding to (hexose) $)_{7}$ (pentose) $)_{2}$ may be derived from LXGGGG, because LXGGGG is not hydrolyzed by $\beta$-D-glcase and IPase. The peak at $\mathrm{m} / \mathrm{z} 1278.88$ corresponding to (hexose $)_{6}(\text { pentose })_{2}$ may be derived from LXGGG, because the non-reducing end Glc residue of GLXGGG is hydrolyzed by $\beta$-D-glcase. The peak at $\mathrm{m} / \mathrm{z} 1146.42$ corresponding to (hexose) $)_{6}$ (pentose) $)_{1}$ may be derived from LGGGG, because one isoprimeverose (X) molecule is split off from XLGGGG by IPase. The peaks at $\mathrm{m} / \mathrm{z}$ 984.509 corresponding to (hexose) $)_{5}(\text { pentose })_{1}$ may be derived from LGGG, because the non-reducing end Glc residue and isoprimeverose $(\mathrm{X})$ residue are split off from GXLGGG by $\beta$-D-glcase and IPase. The oligosaccharide XXGGGGG was hydrolyzed completely into $\mathrm{X}$ (isoprimeverose) and $\mathrm{G}$ (glucose) by $\beta$-D-glcase and IPase.

Next fraction 17 was treated with Oxg-RCBH and the product was subjected to MALDI-TOF-MS analysis (Fig. 8C). The peak at $\mathrm{m} / \mathrm{z} 1116.52$ corresponding to



Fig. 8. MALDI-TOF-MS of $\beta$-D-galase treated fraction 17 (A), of $\beta$-D-glcase and M9 IPase treated fraction $17(\mathrm{~B})$, and of Oxg-RCBH treated fraction 17 (C).

(hexose) $)_{5}$ (pentose) $)_{2}$ may be derived from GLXG, because this GLXG is produced by splitting off one cellobiose (GG) residue from the reducing end of GLXGGG by Oxg-RCBH. The peak at $\mathrm{m} / \mathrm{z} 792.241$ corresponding to (hexose $)_{3}$ (pentose) $)_{2}$ may be derived from both XL and LX, because the former and the latter are produced by splitting off two cellobiose (GG) residues from the reducing end of 


\begin{tabular}{|c|c|c|c|}
\hline \multirow{2}{*}{$\begin{array}{l}\text { oligosaccharide in } \\
\text { fr. } 17\end{array}$} & \multicolumn{3}{|c|}{ oligosaccharides obtained by } \\
\hline & & e & Oxg \\
\hline  & $\begin{array}{c}\text { Gal } \\
\text { Xyl Xyl } \\
\int_{\text {Gle-Gle-Gle-Gle-Gle-Glc }} \\
\text { XXGGGG } \\
\end{array}$ & 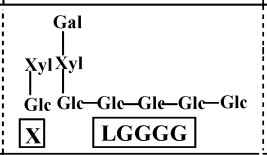 & 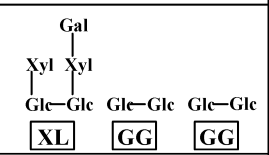 \\
\hline 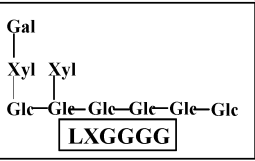 & 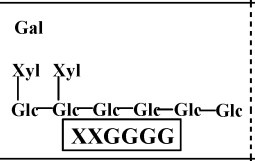 & 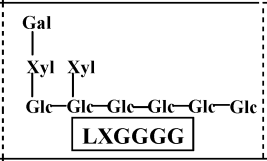 &  \\
\hline 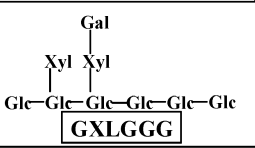 & 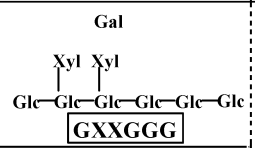 & 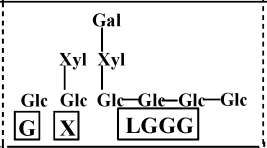 & 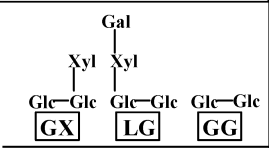 \\
\hline  & $\begin{array}{c}\text { Gal } \\
\int^{\text {Xyl }} \text { Xyl } \\
\text { Gle-Gle-Gle-Gle-Gle-Glc } \\
\text { GXXGGG }\end{array}$ & 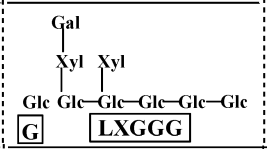 &  \\
\hline $\begin{array}{l}\text { XXGGGGG } \\
\text { le-Gle-Gle-Gle-Gle-Gl } \\
\end{array}$ & $\begin{array}{c}\text { Xyl } \\
\text { Xle-Gle-Gle-Gle-Gle-G } \\
\text { XXGGGG }\end{array}$ & 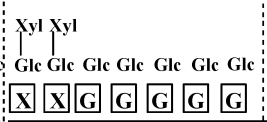 &  \\
\hline
\end{tabular}

Fig. 9. Proposed structures of oligosaccharides in fraction 17, and those of oligosaccharides obtained by hydrolysis of fraction 17 with $\beta$-D-galase, with $\beta$-D-glcase and M9 IPase, or with Oxg-RCBH.

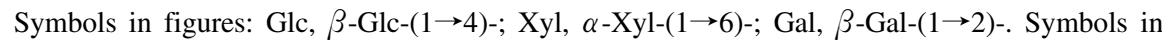
$\square$, see abbreviations.

XLGGGG and LXGGGG, respectively, by Oxg-RCBH. The peaks at $\mathrm{m} / \mathrm{z} 660.159$ and 498.051 corresponding to (hexose $)_{3}(\text { pentose })_{1}$ and (hexose $)_{2}(\text { pentose })_{1}$ may be derived from LG and GX, respectively, because these LG and GX are produced from GXLGGG by Oxg-RCBH.

On the basis of the modes of action of M128 Xg-ase, M9 IPase, $\beta$-D-glcase, $\beta$-D-galase and $\mathrm{Oxg}-\mathrm{RCBH}$, it is reasonable to conclude that nonasaccharide contains XLGGGG, LXGGGG, GXLGGG, GLXGGG and XXGGGGG (Fig. 9).

\section{Analysis of bamboo shoot xyloglucan.}

We previously reported that bamboo shoot xyloglucan was built up predominantly of repeating-oligosaccharide units of XXG, XG and GG. ${ }^{6}$ ) To obtain accurate information on the arrangement of the Glc residues which are not xylosylated at $O-6$ in the $\beta$-1,4-D-glucan backbone of bamboo shoot xyloglucan, the fragmentation analysis of bamboo shoot xyloglucan $(2.4 \mathrm{mg})$ was carried out in a manner almost identical with that described for barley xyloglucan. Tetra- $(127 \mu \mathrm{g})$, penta- $(123 \mu \mathrm{g})$, hexa- (247 $\mu \mathrm{g})$, hepta- $(347 \mu \mathrm{g})$, octa- $(499 \mu \mathrm{g})$ and nona-saccharide $(272 \mu \mathrm{g})$ fractions were obtained as major oligosaccharide fractions, which might be composed of XX, of XXG, of XXGG, XLG and LXG, of XXGGG, LXGG, XLGG, LLG and XXXG, of XLGGG, LXGGG, XXGGGG, LLGG and XXLG, and of XLGGGG, LXGGGG, GXLGGG, GLXGGG and XXGGGGG, respectively. These results suggest that the bamboo shoot xyloglucan also has regions consisting of two, three, four and five contiguous glucose residues which are not xylosylated at $O-6$ in the $\beta-1,4-\mathrm{D}$-glucan backbone.

General discussion.

Structural analyses of the fragment oligosaccharides re- vealed regions consisting of two, three, four and five contiguous Glc residues which are not xylosylated at $O-6$ in the $\beta$-1,4-D-glucan backbone of barley and bamboo shoot xyloglucans. The previous results ${ }^{13)}$ and present results indicate a high degree of regularity in the arrangement of unsubstituted Glc residues along the $\beta$-glucan backbone in Solanaceae xyloglucans, and no regularity in that in Gramineae xyloglucan.

We concluded that the method used for structural study of Solanaceae and Gramineae xyloglucans involving digestion with xyloglucan-specific enzyme (Xg-ase, IPase and $\mathrm{Oxg}-\mathrm{RCBH}$ ) followed by MALDI-TOF-MS analysis is quite useful for clarifying the branching pattern and the arrangement of the Glc residues which are not xylosylated at $O-6$ in the $\beta-1,4-\mathrm{D}-$ glucan backbone of the xyloglucans.

\section{REFERENCES}

1 ) S.C. Fry, W.S. York, P. Albersheim, A. Darvill, T. Hayashi, J. P. Joseleau, Y. Kato, E.P. Lorences, G.A. Maclachlan, M. McNeil, A.J. Mort, J.S.G. Reid, H.U. Seitz, R.R. Selvendran, A.G.J. Voragen and A.R. White: An unambiguous nomenclature for xyloglucan-derived oligosaccharides. Physiol. Plant., 89, 1-3 (1993).

2 ) T. Hayashi: Xyloglucans in the primary cell wall. Annu. Rev. Plant Physiol. Mol. Biol., 40, 139-168 (1989).

3 ) Y. Kato and K. Matsuda: Examination of the fine structures of xyloglucans using endo- $(1 \rightarrow 4)-\beta$-D-glucanases. in Methods in Carbohydrate Chemistry, Vol. X, J.N. BeMiller, D.J. Manners, R.J. Sturgeon and R.L. Whistler, eds., John Wiley \& Sons, Inc., New York, pp. 207-216 (1994).

4 ) Y. Kato, K. Iki and K. Matsuda: Cell-wall polysaccharides of immature barley plants. II. Characterization of a xyloglucan. Agric. Biol. Chem., 45, 2745-2753 (1981).

5 ) Y. Kato, S. Ito, K. Iki and K. Matsuda: Xyloglucan and $\beta$-Dglucan in cell walls of rice seedlings. Plant Cell Physiol., 23, 351-364 (1982). 
$6)$ Y. Kato, R. Shiozawa, S. Takeda, S. Ito and K. Matsuda: Structural investigation of a $\beta$-D-glucan and a xyloglucan from bamboo-shoot cell-walls. Carbohydr. Res., 109, 233-248 (1982).

7 ) S. Eda and K. Kato: An arabinoxyloglucan isolated from the midrib of the leaves of Nicotiana tabacum. Agric. Biol. Chem., 42, 351-357 (1978).

8 ) M. Mori, S. Eda and K. Kato: Two xyloglucan oligosaccharides obtained by cellulase-degradation of tobacco arabinoxyloglucan. Agric. Biol. Chem., 43, 145-149 (1979).

9 ) S.G. Ring and R.R. Selvendran: An arabinogalactoxyloglucan from the cell wall of Solanum tuberosum. Phytochemistry, 20, 2511-2519 (1981).

10) J.-P. Vincken, A.J.M. Wijsman, G. Beldman, W.M.A. Niessen and A.G.J. Voragen: Potato xyloglucan is built from XXGGtype subunits. Carbohydr. Res., 288, 219-232 (1996).

11) I.M. Sims, S.L.A. Munro, G. Currie, D. Craik and A. Bacic: Structural characterization of xyloglucan secreted by suspension-cultured cells of Nicotiana plumbaginifolia. Carbohydr. Res., 293, 147-172 (1996).

12) W.S. York, V.S.K. Kolli, R. Orlando, P. Albersheim and A.G. Darvill: The structures of arabinoxyloglucans produced by solanaceous plants. Carbohydr. Res., 285, 99-128 (1996).

13) Y. Kato, T. Konishi, Y. Hidano and Y. Mitsuishi: Structural analysis of the eggplant xyloglucan by xyloglucanase. J. Appl. Glycosci., 51, 93-99 (2004).

14) K. Yaoi and Y. Mitsuishi: Purification, characterization, cDNA cloning, and expression of a xyloglucan endoglucanase from Geotrichum sp. M128. FEBS Lett., 560, 45-50 (2004).

15) K. Yaoi and Y. Mitsuishi: Purification, characterization, cloning and expression of a novel xyloglucan-specific glycosidase, oligoxyloglucan reducing end-specific cellobiohydrolase. $J$. Biol. Chem., 277, 48276-48281 (2002).

16) Y. Mitsuishi, T. Kato and Y. Kosugi: Characterization of isoprimeverose producing enzyme produced by fungal strain M9. in Abstracts of Papers, Society for Fermentation and Bioengineering, Japan, Osaka, p. 103 (1992)

17) M. Dubois, K.A. Gilles, J.K. Hamilton, P.A. Rebers and F. Smith: Colorimetric method for determination of sugars and related substances. Anal. Chem., 28, 350-356 (1956).

18) T. Watanabe, Y. Mitsuishi and Y. Kato: Isolation and characterization of an acidic xylan from Jojoba (Simmondsia chinensis) hulls. J. Appl. Glycosci., 46, 281-284 (1999).

\section{キシログルカナーゼによる大麦 およびタケノコキシログルカンの構造}

加藤陽治 ${ }^{1}$, 伊藤聖子 ${ }^{1}$, 三石 安 $^{2}$

1 弘前大学教育学部食物学研究室

（036-8560 弘前市文京町 1)

2 独立行政法人産業技術総合研究所つくば中央第六事業所

$$
\text { (305-8566つくば市東 1-1-1) }
$$

大麦幼植物およびタケノコ細胞壁からキシログルカン 多糖を分離した。これに，精製キシログルカナーゼ $(\mathrm{Xg}$ ase)を作用させ，HPLCにより重合度 4-9 のキシログル カンオリゴ糖画分を得た。各キシログルカンオリゴ糖画 分は，それぞれ， $\beta$-D-ガラクトシダーゼ( $\beta$-D-galase $)$, $\beta$-D-グルコシダーゼ( $\beta$-D-glcase $),$ 精製イソプリメべ ロース生成酵素 (IPase) および精製キシログルカンオリ ゴ糖分解酵素 $(\mathrm{Oxg}-\mathrm{RCBH})$ による加水分解を行い, 生 成物を MALDI-TOF-MS 法にて解析した。 大麦のキシロ グルカンを構成している主要オリゴ糖単位として, 四糖 $(\mathrm{XX})$ ，五糖 (XXG)，六糖 (XXGG)，七糖 (XXGGG， LXGG), 八糖 (XLGGG, LXGGG, XXGGGG, GXXGGG), および九糖 (XLGGGG, LXGGGG, GXLGGG, GLXGGG, XXGGGGG) の存在が確認された。［XX等はFry らによ るキシログルカンオリゴ糖の表示法で主鎖の各(1 $1 \rightarrow 4)-$ $\beta$ 結合のグルコース残基の分岐様式により一文字コード で示される. $\mathrm{G}=\beta$-D-Glc ; $\mathrm{X}=\alpha$-D-Xyl-(1-6)- $\beta$-D-Glc; $\mathrm{L}=\beta$-D-Gal-( $1 \rightarrow 2)-\alpha$-D-Xyl- $(1 \rightarrow 6)-\beta-\mathrm{D}-\mathrm{Glc}]$. また, 夕 ケノコの場合も大麦と類似した構造単位が確認された。 これらの結果より，イネ科植物の大麦およびタケノコの キシログルカンには側鎖をもつ構造単位の間に, セロビ オース (GG) からセロペンタオース (GGGGG) に相当す る配列の存在が明らかとなった。 